\title{
Study on Effective Citizenship Education and Its Dimensions
}

\author{
Irem Namli Altintaş, Hüseyin Karaaslan*
}

Social Studies Education, Süleyman Demirel University, Turkey

Copyright $\mathrm{C} 2019$ by authors, all rights reserved. Authors agree that this article remains permanently open access under the terms of the Creative Commons Attribution License 4.0 International License

\begin{abstract}
The aim of this study is to compare the dimensions of citizenship education among European countries, United States (USA) and Turkey, and discuss these dimensions in a manner that explores effective citizenship education. The dimensions are discovered through a factor analysis of the scales applied to students regarding citizenship education. In this study, literature review method, which is one of the qualitative study methods, is used. The data contains 6 scales from Europe, USA and Turkey. The common dimensions between scales, being applied to teachers or students and quantitative data are considered when choosing scales. The study is qualitative in this dimension. The content of the common dimensions of the scales is analyzed. As a result of the analysis, it is determined that the common dimensions of the scales applied in European countries and USA are knowledge, skills, citizenship duty, citizenship values, volunteering, participation and protest. It is found that the civic duty and volunteering dimensions are not included in the scales applied in Turkey, and protest dimension is seen as a subcategory of participation. The study discusses the goal of establishing effective citizenship education while taking Turkish and Western cultures, and different and common dimensions into consideration.
\end{abstract}

Keywords Effective Citizenship, Effective Citizenship Education, Citizenship Education Scales, Cultural Differences, the Dimensions of Effective Citizenship

\section{Introduction}

The meaning of citizenship education may change depending on the politics, political situation and historical roots of the country. When various definitions of effective citizenship are examined, it is seen that these definitions vary with the cultures and time. The meaning assigned to the citizen, society and politics affects the citizenship education. The characteristics of the desired citizen define the main attributes of effective citizenship. For example, the education focuses on citizenship duties if the citizens are expected to love their country, to pay taxes and to work. On the other hand, if the citizens are expected to actively participate in government, the education focuses on effective citizenship.

According to European Commission's definition in 1998, the effective citizenship is seen when the citizens speak out for the associations that they are members of, or for communities that share their ideals, and thus feel a sense of identity, have a clear set of values and improve their social solidarity [17]. Based on this report, Hoskins and Mascherini [22] defined effective citizenship as a way of empowering the citizens to speak out for their sense of belonging, their interests, democratic values, equality and the ability to understand different cultures and ideas.

According to Hoskins [20] in civil society, communities and/or political life, effective citizenship falls within the framework of mutual respect, democracy and compliance with human rights, without resorting to violence. With CRELL (Centre for Research on Education and Lifelong Learning), Hoskins also defined effective citizenship as participation in civil society, public sphere or politics, based on mutual respect, non-violence and compliance with human rights and democracy.

Hombers, D'hombres and Campell [21] defined effective citizenship as a way for citizens to empower themselves in order to make their voices heard more in society, to strengthen their sense of belonging, to have different cultures and ideas, and to appreciate the values of democracy and equality.

According to a brief and clear definition, effective citizenship empowers individuals to directly influence the decision-making processes in society and voluntary organizations (http://www.aughty.org).

According to Wood [43], effective citizenship is associated with membership, responsibility and having mastery over small dimensions of politics. It is also associated with participation in social life and learning. 
Contrary to Wood's definition, Clarke and Missingham [9] define the concept as the relationship between unequal parties, especially between citizens and government.

When examining these definitions, whether we study the citizenship from government's or from the citizens' point of view gains importance. Respect among individuals, democracy, harmony within society and non-violent protests stand out in definitions.

According to Eryllmaz, Bursa and Ersoy [16], effective citizenship means that the individual participates in actions to achieve social justice.

Effective citizenship definitions are considered important in determining the position of an individual regarding social values. For example, the European Commission has taken into account the issue of European citizenship and emphasized that the people living in the continent have the right to the land, and that they must first have a sense of belonging in order to obtain their rights.

Whether an individual is an effective citizen has been assessed in terms of the individual's feelings of belonging and in relation to his cultural values, his political life, respect for other people, and how he defends his interests. The definitions also show that the sense of belonging brings social and political responsibilities. The responsibility may be seen as active membership in nongovernmental organizations (Wood [43]; http://www.aughty.org), active participation in politics [20] or the understanding of different ideas [21].

As we have seen, effective citizenship is not only about the individuals themselves but also about being interested in the social and political environment and volunteering about these issues. Based on these definitions, considering government institutions and citizens' relationship with these institutions important for effective citizenship [9] shows that effective citizenship can be evaluated not only with regards to citizens but also with regards to citizen-government relations. In Addition, effective citizens know the use of information [8].

In this study, effective citizenship scales are examined as dimensions and their sub-categories. It is found that in the studies regarding the values and attitudes, the researchers are not able to answer the question "how an effective citizenship education should be?" satisfactorily, and had problems in finding appropriate evaluation tools regarding the subject. Therefore, this study may be an important resource for researchers working in this field.

Teachers' and students' view on effective citizenship has been addressed in several studies. The common goal of these studies is to develop an argument regarding how schools should help students to cultivate effective citizenship. There is no doubt that these arguments vary with the culture. In this study, the effective citizenship scales in Europe, USA and Turkey are examined qualitatively and how effective citizenship education should be is discussed.

There are very limited studies on dimensions of effective citizenship. For example, Danju and Uzunboylu [12] have done content analysis on citizenship education, sample groups, number of authors, research methods that they have used and data collection methods. However, in this study, the quantitative measurement tools are examined qualitatively. Therefore, the study's distinct contribution to the area is that it establishes the dimensions that define how effective citizenship education should be.

\subsection{Purpose of the Study}

The purpose of this study is to discuss the educational arguments about how the education should be by defining the dimensions of the scales applied to effective citizenship education. These arguments consist of the concepts, the teaching methods and the roles of schools, teachers, and students.

\section{Materials and Methods}

\subsection{Method of the Study}

In this study, literature review method, which is one of the qualitative study methods, is used. Definitions of effective citizenship and related scales are used as documents. In social sciences, there are a lot more discussions about what a document means. Records of interviews, written documents (letters, treaties, etc.) [15], or personal/official written documents, photographs, image records [4] may be accepted as documents. This method is chosen for identifying the data sources that other researchers are using and for establishing a connection between the concepts and scales [24].

\subsection{Data Collection}

By gathering documents that have similar problems, methods and answers, and searching for common findings, this study aims to create a new perspective [24].

The data in this study are collected through scales that examine the views of students or teachers at each level of education, regarding effective citizenship. Researchers organized similar scales in chronological order and examined common dimensions. In the literature review method, the researchers always try to decide when the review should end. In this study, some limitations are defined to make the focus of the study clear [24]. These limits include: the size of the applied scales intersecting with other scales, the application of the scales on teachers or students, and the quantitative improvement of the measuring tool. In the study, 6 scales from Turkey, Europe and USA are used.

\subsection{Analysis of the Data}

The data in this study is analyzed by content analysis 
method. The reason content analysis is used to explore common areas and help new researches [15]. Thus, the reader and the researcher would be able to receive the same message [5]. The scales used for effective citizenship education are gathered and the number of sub-categories, samples, dimensions and sub-categories related to these dimensions are determined. The aim is to determine whether the scales should be included in the study, or not. Indeed, there are scales that are not included in the study.

The dimensions and sub-categories of the scales that are applied in effective citizenship education are coded and categorized together. The codes are defined according to the literature, and a framework, which is established to show how effective citizenship education should be.

The content analysis for the scales used in Europe-USA and Turkey are done separately. Thus, a literature review on cultural difference is also conducted.

\subsection{Validity and Reliability Studies}

Validity and reliability studies in the research are done for common dimensions of the scales.

First of all, internal validity has been tested: The data was found as the result of the analysis have been checked in the literature. The researchers concluded that the dimensions that are found fit into the previous conceptual framework and have internal integrity. Moreover, for external validity, common dimensions that are found consistent with each other, can be retested in similar environments and are found to be compatible with the outside world.

In the literature review, after the analysis, it is concluded that there are many studies on the dimensions related to effective citizenship and that these studies find the correspondence in real life. This increases the credibility of the study. The coding of the data was done by more than one researcher and the comparisons showed the reliability of the study [31]. As a result of the analysis, researchers have been satisfied regarding how effective citizenship education should be.

\section{Findings}

\subsection{The Scaling Methods Used in Europe and USA for Effective Citizenship Education}

In this part of the research, scales developed for effective citizenship education and samples, items and dimensions of these scales are defined.

The first scale developed is a scale used by Westheimer and Kahne [42] for citizenship classifications. Researchers have focused on the concept of a good citizen and the role of a good citizen in democratic education programs. In the study, citizenship types were classified into three categories: citizens with personal responsibility, participants and justice-focused citizens. The reasons for choosing the categories used in this theoretical classification are that the categories have good theoretical basis, reflect the democratic education goals of the teachers, and reflect the ideas and ideals of the individuals who prepare the education programs, teachers and the educators. Qualitative and quantitative methods are used together in the research. Surveys, observations and interviews are used as data collection tools in the study. The sample of the study consists of 61 students and 2 teachers in Madison, the USA and 23 students in Bayside, USA. As a result, the factor analysis of the surveys is applied to students in Madison, the dimensions of personal responsibility and helping others, participation in groups, interest in politics, individual efforts for preventing poverty, willingness to work for achieving justice, effectiveness of citizens, vision, social capital, effectiveness of leaders, following the news, the government's responsibility towards those in need, employers' responsibility towards employees are found.

Kennedy [27] aims to show how students identify themselves as effective citizens by using the IEA (International Association for Evaluation of Educational Achievement) and Civic Education Study data. The survey sample consisted of 90,000 students from 28 countries in Europe with an average age of 14.7 and after the data had been extracted, 12,500 students from 25 countries were chosen as the sample. The data were obtained on a 12-item scale. The four dimensions of the scale resulting from factor analysis are political obligations, political rights, volunteer activities and protest.

Zaff, Boyd, Li, Lerner and Lerner [44] aimed to combine the active and participatory citizenship with civil participation, including behavioral, cognitive and socio-emotional structures. The data of the study were collected on a scale consisting of 42 items and 6 categories. The sample of the study consists of 909 students living in Europe, $62.4 \%$ female and $37.6 \%$ male. These students are studying at the 8th, 9th and 10th grade levels. An exploratory factor analysis was performed on the collected data and it is found that dimensions of active and participatory citizenship are citizenship tasks, citizenship skills, social communication and citizenship participation ${ }^{1}$.

Hoskins, Saisana, and Villabla [23] aimed to develop a scale that demonstrates the level of young people's citizenship qualifications by using the data ${ }^{2}$ from the IEA

1 The pattern that the 4-H organization uses in the Positive Youth Development Project is referenced in this study. See https://4-h.org/about/what-is-4-h/

2 The ICCS (2009) survey aims to examine how young people are prepared to undertake citizenship duties. The basis of the study consists of 4 dimensions, namely civil society and systems, citizenship principles, citizenship participation and citizenship identity, and 2 cognitive areas, knowing and thinking. The data were collected through an international cognitive student test, an international student questionnaire and a regional data collection tool to examine individuals. The International Cognitive Student Test is a test consisting of 80 questions and 7 booklets measuring civil knowledge, citizenship knowledge, analysis and reasoning. The international student questionnaire is a data collection tool that evaluates students' civil and citizenship perceptions and compiles data 
ICCS 2009 survey. An 80-item cognitive test was prepared on this scale. The study consists of four main themes: civil society and systems, citizenship principles, citizenship participation and citizenship identity. ICCS is a study conducted in 38 European countries in 2009, research includes 140,000 eighth grade students, 62,000 teachers and 5,300 schoolmasters. The average age of the students is 13.5. As a result of factor analysis, four dimensions were found regarding citizenship qualifications: citizenship values, social justice, participatory attitudes and knowledge and skills for democracy.

Lara, Deane and Pavlouau [28] aimed to explain what effective citizenship is and how to define it, in their work. A 15 -item scale was used as a data collection tool. The 3 scales developed in the study were applied to 20 undergraduate students as pilot application after receiving expert opinion. The scale was then applied to 923 undergraduate students studying at UK universities. The data were analyzed by descriptive factor analysis and the dimensions of the scale found as knowledge and awareness of differences, taking action for society, improving society and pioneering attitudes.

The study of Rynkiewicz and Zalewska [37] was conducted under the influence of Kennedy's research [26] and [45]Zalewska and Krzywosz-Rynkiewicz research [45]. The study was conducted to determine the citizenship behavior of young people. Data were collected using a 4-point likert type Citizenship Behavior Questionnaire, consisting of 34 questions applied to 293 students aged 11, 14 and 17 years in Poland. The scale consists of three main categories: passive citizenship, active citizenship and semi-active citizenship. In this study, the same scale was applied to the students in two European cities, One big and one small were selected from each country in the 42 European countries and surrounding countries. Participation was on a voluntary basis and participants consisted of 4920 students aged 11-18 years.

When examined in general, it appears that the scales are applied to students in Europe and the United States. One is applied in England. When scales are developed, generally quantitative methods are used. Westheimer and Kahne [42], which examine political dimensions, have used qualitative and quantitative methods in defining the types of citizenship. In addition, 4-point scales with at least 12 items were developed. Theoretical studies have been taken into account regarding data collection tools or research companies have been hired to prepare them. For this reason, sample sizes range from 900 to 15,000 .

Table 1 presents the dimensions of the scales applied for effective citizenship in the US and European countries. It is observed that the scale studies on active citizenship were conducted between 2004 and 2017. The Westheimer and Kahne [42] study shows that Rynkiewicz and Zalewska [37] is the least dimensioned research with the highest dimension in 10 dimensions.

The majority of the size of the scale developed in Turkey is related to political participation.

on students' readiness. The regional data collection tool for learning about individuals, is a measuring tool for the cognitive level, designed separately for Asian, European and Latin American countries. The data were collected through an international cognitive student test, an international student questionnaire and a regional data collection tool to examine individuals. The International Cognitive Student Test is a test consisting of 80 questions and 7 booklets measuring civil knowledge, citizenship knowledge, analysis and reasoning. The international student questionnaire is a data collection tool that evaluates students' civil and citizenship perceptions and compiles data on students' readiness. The regional data collection tool for learning about individuals, is a measuring tool for the cognitive level, designed separately for Asian, European and Latin American countries. 
Table 1. Scales and dimensions of effective citizenship in the US and European countries

\begin{tabular}{ll}
\hline Researchers & Dimensions \\
\hline Westheimer and Kahne (2004) & $\begin{array}{l}\text { Personal Responsibility and Helping Others, Participation in Groups, Interest in } \\
\text { Politics, Individual Efforts for Preventing Poverty, Willingness to Workfor Achieving } \\
\text { Justice, Effectiveness of Citizens, Vision, Social Capital, Effectiveness of Leaders, } \\
\text { Following the News, the Government's Responsibility Towards Those in Need, } \\
\text { Employers' Responsibility Towards Employees }\end{array}$ \\
\hline Kennedy (2007) & Political Obligations, Political Rights, Volunteer Activities and Protest. \\
\hline Zaff, Boyd, Li, Lerner and Lerner (2010) & $\begin{array}{l}\text { Active and Participatory Citizenship are Citizenship Tasks, Citizenship Skills, Social } \\
\text { Communication and Citizenship Participation }\end{array}$ \\
\hline Hoskins, Saisana, and Villabla (2015) & $\begin{array}{l}\text { Citizenship Values, Social justice, Participatory Attitudes and Knowledge and Skills } \\
\text { for Democracy. }\end{array}$ \\
\hline Lara, Deane and Pavlouau (2016) & $\begin{array}{l}\text { Knowledge and Awareness of Differences, Taking Action for Society, Improving } \\
\text { Society and Pioneering Attitudes. }\end{array}$ \\
\hline Rynkiewicz and Zalewska (2017) & Passive Citizenship, Active Citizenship and Semi-active Citizenship \\
\hline
\end{tabular}

\section{2. The Effective Citizenship Scales Developed in Turkey}

In this section, effective citizenship scales developed in Turkey are examined.

The first one is Citizenship Inclinations Scale [18]. This scale consists of 3 sub-categories and 84 items. These categories are knowledge, behavior and values. The pilot study of the scale was conducted with 150 teacher candidates at a state university. The researcher divided the study into categories. These categories are: active participation; production, consumption and economy; environmental awareness; global issues; democracy; respect and equality; society and individual.

In his study, Saglam [33] aimed to determine the effective citizenship levels of teacher candidates. The sample of the study consists of 317 social studies and primary school teacher candidates, 182 women $(57 \%)$ and 135 men (43\%), who are studying at the third and fourth grade level in a state university. The 30-item Effective Citizenship Qualifications Scale, which was created as a data collection tool for the study, was rearranged after receiving an expert opinion and turned into a 24-item cinque likert type scale. As a result of the analysis of the data, an item which is not compatible with the scale was excluded and the scale gained a structure consisting of 23 items and two categories. These categories are: citizenship values and citizenship knowledge and skills.

Cevik-Kansu ve Oksuz [11] developed The Effective Citizenship Scale by applying the scale to 568 students, studying in a primary school in Bayburt. The scale consists of 42 items. It consists of 4 factors: environment awareness, interest in activities, social response and voluntary participation.

Keçe and Dinç [26] aimed to develop a measurement tool that takes into account the demographic characteristics of university students, and measures their democratic participation levels. The sample of the study consists of 485 students, 287 female and 198 male, from Faculty of Education, Science and Letters, Engineering, and Economics and Administrative Sciences of a state university. The relevant literature has been examined during the development of the measurement tool and it has been understood that democratic participation consists of two dimensions: political participation and social participation. The scale has a 5-point likert type structure consisting of 61 items. After the sample is evaluated according to the scale, the data were analyzed using factor analysis and unsuited items were excluded from the scale. After excluding 3 items in the political participation and 6 items in the social participation categories, the scale has gained a structure consisting 52 items. The political participation category involves: expressing an opinion in visual and written media, awareness towards elections, protests and marches, election rallies, being informed about services and policies, propaganda, boycott and strikes. The social participation involves: expressing an opinion on social matters, NGOs (Non-Governmental Organizations) solidarity, following social agenda, taking action to solve social problems or participating in NGOs.

Namli-Altıntas and Kozaner [32] developed the Effective Citizenship Value Scale. For the development of the scale, the scale is applied to 400 students, between the ages of 18-22, studying in the education faculty of a state university. However, because of the data loss, only the data from 392 students were valid. The scale consists of 18 items. The scale showed 4 dimensions: Republican and effective citizenship values, giving importance to effective citizenship, not making discrimination and supporting others to become effective.

Yazici, Arslan, Cetin and Dil [41] aimed to develop the Effective Citizenship Assessment Tool (ECAT). Researchers have mostly used the European Social Survey questionnaire (www.europeansocialsurvey.org) and the theoretical framework of The Active Citizenship Composite Indicator (ACCI) when developing measurement tools [22]. ECAT is a likert type scale consisting of 73 questions, 4 categories and 8 sub-categories. Scale consists of questions with 5 possible answers and only questions regarding memberships have 2 possible answers: Yes or No. The sample size of the scale is 635 individuals, 311 (49\%) male and 321 (50,9\%) female. 
The data were collected using face-to-face interview method. The scale was analyzed after it was applied on the sample and it was found that the scale consists of 4 categories: knowledge, skill, value and participation. The knowledge category consists knowledge and awareness through following news; skills consists citizenship self-efficacy; value consists democratic values such as equality and solidarity; and participation consists group membership, participation in groups and marches and protests sub-categories.

In general, it is observed that the scales related to effective citizenship education are applied to teacher candidates studying in education faculties. Accordingly, the sample size varies between 150-700. When measuring tools were developed, qualitative methods were almost never utilized. The scales consisted of at least 18 items and 4 categories. For creating data collection tools, theoretical works have been used, as seen in other countries.

The dimensions occurring in the applied scale for active citizenship in Turkey are given in Table 2 . The studies are between 2010 and 2017. In the table, it is seen that the research, which has the largest number of dimensions belongs to Göz [18] and the least dimension is Kece and Dinc [26]. Overall when examining the scales in Turkey it has emerged as dimensions associated with citizenship values.

Tables 1 and 2 compared the related studies on the scale of active citizenship in the US and European countries, according to studies conducted in Turkey seems to start earlier. It can also be said that there is a difference between citizenship values and political participation. They measure the social life in Turkey and Europe when establishing a link between active citizenship and political participation size scale in America, where volunteerism has emerged as the size scale protests.

Table 2. Scale and dimensions of active citizenship in Turkey

\begin{tabular}{|c|c|}
\hline Researchers & Dimensions \\
\hline Göz (2010) & $\begin{array}{l}\text { Active Participation; Production, } \\
\text { Consumption and Economy; } \\
\text { Environmental Awareness; Global } \\
\text { Issues; Democracy; Respect and } \\
\text { Equality; Society and Individual. }\end{array}$ \\
\hline Sağlam (2011) & $\begin{array}{l}\text { Citizenship Values and Citizenship } \\
\text { Knowledge and Skills. }\end{array}$ \\
\hline $\begin{array}{l}\text { Çevik-Kansu } \\
\text { Oksuz (2014) }\end{array}$ & $\begin{array}{l}\text { Environment Awareness, Interest in } \\
\text { Activities, Social Response and } \\
\text { Voluntary Participation. }\end{array}$ \\
\hline Keçe and Dinç (2015) & $\begin{array}{l}\text { Political Participation, Social } \\
\text { Participation. }\end{array}$ \\
\hline $\begin{array}{l}\text { Namli-Altıntas and } \\
\text { Kozaner (2016) }\end{array}$ & $\begin{array}{l}\text { Republican and Effective Citizenship } \\
\text { Values, Giving Importance to Effective } \\
\text { Citizenship, Not Making Discrimination } \\
\text { and Supporting Others to Become } \\
\text { Effective. }\end{array}$ \\
\hline $\begin{array}{l}\text { Yazici, Arslan, Cetin } \\
\text { and Dil (2017) }\end{array}$ & $\begin{array}{l}\text { Knowledge, Skill, Value and } \\
\text { Participation. }\end{array}$ \\
\hline
\end{tabular}

\subsection{Common Dimensions of Effective Citizenship Education}

In this part of the study, common dimensions of the scales are examined and sample items are listed or sub-categories are explained.

\subsubsection{Knowledge}

Effective citizenship education is primarily based on formal education. It is a part of the formal education that students obtain basic knowledge about citizenship.

Hoskins [20] categorized knowledge in effective citizenship education as past knowledge, realistic knowledge, and functional knowledge. He has argued that students should have knowledge about human rights and responsibilities, political literacy, historical knowledge, current developments, cultural heritage, legal issues and their effect on politics to be effective citizens. He also thought that there were some necessary conditions to be able to give effective citizenship education. These were school's financial condition, mixed sex education and specialization.

Hoskins et al. [23] emphasized that in the republican model of citizenship, it is citizens' duty to gain knowledge about his country's historical background. On the scale, "Effective Citizenship Model" consists of democracy knowledge and skills category.

Lara et al. [28], associating knowledge with attitude in cognitive level category, define knowledge as the knowing and understanding of differences. The dimensions such as to be aware of the cultural, ethnic, political, religious, and national backgrounds of other people and to understand that their way of understanding may vary according to local and cultural contexts and have shown to be related to the knowledge dimension of the effective citizenship. Local authorities support citizens to participate more [1].

In researches in Turkey, knowledge dimension is found to be based on formal knowledge. For example, in the scale he developed, Goz [18] defined the lower limits of the citizenship knowledge by using the scale's knowledge dimension. Knowledge includes knowledge on basic concepts of human rights and freedom such as universal declaration of human rights, children's rights, women's rights, constitution, individual rights and freedom, citizenship.

Saglam [32] defined citizenship knowledge and skills as a dimension. For example, items such as knowing how to solve a problem I encounter, knowing how to decide on a topic is included in the knowledge dimension.

Knowledge dimension varies greatly in effective citizenship education in Turkey and European cultures. In Turkish culture, formal conceptual knowledge is given while in Western culture, a change in attitudes is aimed when giving knowledge. This also can be seen in the researches of Lara et al. [28] and Goz [18]. Lara et al. [28] defined a category in which the person knows the cultural 
differences; Goz [18] associates the person's knowledge of the environment, history, human rights and democracy with the effective citizenship knowledge.

Another finding that comes with the knowledge dimension is related to the student's source of knowledge. In the Western culture, institutions that would provide effective citizenship education were evaluated in terms of knowledge; there was no similar situation in Turkish culture.

\subsubsection{Skill}

The way in which a person's knowledge of effective citizenship is transformed into skills and how this knowledge is achieved is about how knowledge is used. For example, Hoskins [20] created Effective Citizenship Qualifications scale that includes skills category. These skills are divided into sub-categories such as: empathy, critical reading, discussion, writing, listening, critical listening and social skills. When related to effective citizenship, the characteristics such as working with others, problem solving, communication, discussion skills, knowledge of decision-making, the power to influence society and politics in this way and self-defense are related with the skill dimension.

In the scale developed by Zaff et al. [44], one of the factors is citizenship skills. These skills are associated with the person expressing himself verbally or in writing. A student expressing himself in front of a group of people, or declaring his ideas in writing in a local newspaper, is related with effective citizenship skills.

Hoskins et al. [23] did not distinguish effective citizenship skills from knowledge dimension and they have come to the conclusion that students will master the knowledge they have acquired through their experiences in individual decision making and literacy.

Skills dimension may also be seen in the studies in Turkey.

Saglam [32] placed knowledge and skills into same category. An item in the skills category is excluded in this study. For example, the items "I have communication skills, I can distinguish the right sources of knowledge" presents a skill.

In Namli-Altintas and Kozaner's study (2016), in the category of supporting other individual's activities, the items: citizens should actively participate in political parties and I support protest marches, defines the skill of supporting citizens to actively participate in society.

In the studies by Yazici et al. [41], skills are defined as sub-category, named citizen self-efficacy.

Skills dimension is a common dimension in Turkish and Western cultures, even though the meaning varies greatly. These skills relate to communication skills or thinking skills. Therefore, there is no agreement on this dimension. The studies in Turkey examine the dimension generally, while in West, the dimension is examined in detail.

\subsubsection{Citizenship Duties}

Although the tasks of citizenship are associated with the republican citizenship, there are still researchers in the literature who discover these dimensions, related to effective citizenship. For example, in Kennedy [26]'s what do you plan to do about political matters in your adulthood? question, one of the dimensions was political duties. The answers "to vote in the national election and have knowledge about the candidates before voting in the elections" provided by the participants have categorized in the political duties dimension.

Zaff et al. [44] also defined the citizenship duties dimension in the scale they developed, and considered "to make a difference in society, to believe that everyone has equal rights" as a duty.

Citizenship duties are defined as an individual dimension and as a right. In other words, taking part in political life is a natural dimension of being an effective citizen and it is every citizen's duty. In studies conducted in Turkey, the duty is not classified as a part of the effective citizenship education. For example, Saglam [32] put knowledge and skill into the same category; however, Zaff et al. [44] considered citizenship skills a separate category. These skills are conceptualized as communication skills.

\subsubsection{Volunteering}

A number of volunteer activities that involve individual decision making abilities have been added to the requirements of effective citizenship, such as knowledge, skills and duties. For example Kennedy [26], have described the volunteering dimension in Expected Political Actions scale, and categorized the items, volunteering for the poor or old individuals in the society, gathering signs for a petition as volunteering.

Pragmatist Level and Attitudinal Level that is in the scale was developed by Lara et al. [28] are included in the volunteering dimension in this study. The individual's desire to improve the society, the desire to make a positive contribution, assuming leadership in his paid/volunteer work, or the counseling his peers are included in the volunteering dimension in this study.

Volunteering dimension is considered the opposite of the citizenship duties. In scales related to effective citizenship, in Western culture, individual's willingness to improve society is defined as volunteering. There is not a similar dimension in the scales developed in Turkey.

\subsubsection{Participation}

The participation dimension in this study is similar to the volunteering dimension.

Zaff et al. [44] has included working as a volunteer-assistant in a church, synagogue, or other place of worship, and helping neighbours in the category of participation.

Hoskins et al. [23] defined the dimension of inclination to participate and give participation more importance than 
traditional citizenship duties and suggested it necessitate volunteering. He categorized participation as participation in elections, participation in politic and social discussions, and taking action regarding domestic political events.

Lara et al. [28] includes volunteer activities when defining participation. For example, in cognitive level dimension, participating in activities and projects related to society and volunteering may be seen as participation.

Rynkiewicz and Zalewska [37] categorized political activity as a sub-category of the effective citizenship dimension in the scale they developed. They defined participation as participating or wanting to participate in a political party, working in a NGO, taking legal political actions and actively participating in political life; and categorized it as political participation. On the other hand, they did not see participation only as a political dimension, but also added a sub-category of social participation. Working voluntarily on behalf of a charity or an environmental/private social group and participating in an organization to protect cultural identities and the people of a region can also be included in this dimension.

In researches in Turkey, participation dimension is seen as a sub-category.

In the scale he developed, Goz [18] defined Active Participation dimension. Teachers' being informed about the activities of central and local governments, being informed about the activities of non-governmental organizations, working voluntarily in any NGO and encourage others to work voluntarily items are categorized in Active Participation dimension.

Cevik-Kansu ans Oksuz [11] defined Volunteer Participation dimension. In this dimension, "I fulfill my tasks given by my teacher, I warn those who harm plants" items are included in volunteer participation.

Kece and Dinc [26] defined sub-categories under Participation dimension. These categories are political participation and social participation. Political participation dimension includes election awareness, election rallies, service and policy follow-up sub-categories. In social participation dimension expressing opinions on social issues, helping NGOs, following social agenda, taking action to solve social problems sub-categories are defined.

Participation dimension can be found in scales, developed both in Turkish and Western cultures, but its meaning varies. Participation can be seen as participating in social or political life. In this dimension, NGOs gain importance in Turkish and Western cultures. Political participation is defined differently in both cultures.

\subsubsection{Protest}

Protest dimension includes a legal, political action.

One of the items in Westheimer and Kahne's [42] Expected Political Actions Scale is protest. The sample item of this dimension is actions such as writing a slogan with spray paint on the walls and preventing traffic with a protest.

Hoskins et al. [23] examined protest as related to citizenship values and defined it as an individual's questioning of political actions. Therefore, in Effective Citizenship Model, protest is defined as a value.

In researches in Turkey, it is seen as a political dimension.

For example in Kece and Dinc's [26] researches in Political Participation dimension, organizational membership, organizational participation sub-categories are defined. Demonstrations and marches, propaganda, boycotts and actions are the three sub-categories of protest.

In the researches of Yazici et al. [41] protest dimension is included in participation sub-category as marches and protests.

This dimension can be found in both Western and Turkish scales. However, its meaning can vary. In Western culture, the protest dimension has taken the form of an action to prevent the occurrence of a political incident [42] or questioning the actions that have been taken [23]. In the scales in Turkey, 2 scales take protest dimension into consideration. One of the scales defines protest as an individual dimension [26], the other defines protest as a sub-category of participation dimension.

\subsubsection{Citizenship Values}

Citizenship values cover a great range in effective citizenship education. Since value can vary according to cultures, your perspective on effective citizenship values will be effected by cultural values.

Westheimer and Kahne [42] have associated the findings of their studies with the students' perspective on effective citizenship values. These values are defined in "Justice Focused Citizen" as personal responsibility and solidarity, participation in groups, interest in politics, individual efforts for poor, willingness to work for justice, effectiveness of citizens, vision, improvement of society, knowledge/social capital, effectiveness of leaders and willingness to volunteer. Researchers also defined "justice -focused citizen" for an effective, democratic society. They suggested that this type of citizen should take action to ensure social justice.

In his study, Hoskins [20] defined citizenship values as a dimension of the concept Effective Citizenship Qualifications. The sub-categories: tolerance, supporting non-violent actions, endorsing the role of human rights and laws are included in this dimension. Equality, validation and democracy are also included in effective citizenship values.

Hoskins et al.'s [23] Citizenship Values in an Effective Citizenship Model dimension is defined as citizenship values in this study. He emphasizes the fact that all activities ranging from traditional citizenship to protest are included in citizenship values.

Lara et al. [28] evaluated citizenship values indirectly as an attitude. These attitudes can be classified as equality, 
development and ideas on social justice.

In the scale developed by Rynkiewicz and Zalewska [37] semi-active citizenship has a sub-category of citizenship values. These values are defined as to vote and to be interested in issues related to public affairs, to participate in moderate and minimal social life and to indirectly contribute to public interest.

In researches in Turkey, citizenship values have defined in different ways.

In his study, Goz [18] defined Environmental Awareness as a sub-category. Teachers' having knowledge about substances harmful to the environment, preferring materials that do not harm the environment and encouraging people to do the same, having knowledge about the recycling process of household wastes, classifying wastes and encouraging people to recycle waste are classified in the scale as Environmental Awareness [18]. On the other hand, Democracy, Respect and Equality can be defined as a value. İtems regarding teachers such as: they must be knowledgeable about the factors that determine people's rights and behave equally and respectfully by not discriminating based on differences such as language, religion and race; recognize that different thinkers in the community brings richness, tolerate differences and behave respectfully can be categorized as values in this study.

In his study, Saglam [33] defined citizenship values dimension. "I am against all kinds of discrimination, I am tolerant of different ideas" items are included in citizenship values dimension.

In their research, Cevik-Kansu and Oksuz [11] defined Environmental Awareness dimension, which is classified as citizenship values in this study. "I believe that the work of Red Crescent is useful, I would like to work in non-governmental organizations, I feel uncomfortable with throwing the trash around the picnic areas" items are categorized in citizenship values dimension.

In Namli-Altintas and Kozaner's study [32], Republic, values and discrimination dimensions are classified as citizenship values. "Protecting democracy is a civic duty or Republic is an important achievement for our country" items are included in Republic and Values dimension. Discrimination dimension includes items: I judge people based on the political part that they are members of or I think I discriminate against some ethnic minorities in my country .

Yazici et al. [41] defined Values dimension directly. This dimension has sub-categories of equality, solidarity and democratic values.

The definition of citizenship values dimension varies as skills dimension does. Despite this, it is a common dimension in Turkish and Western cultures. In western culture, the individual's respect for the society and law, and working for society can be classified as values. In studies in Turkey, the dimension that reflects the individual's opinions on his environment is classified as a value. This environment can be natural environment or social environment.

In Table 3, the dimensions of the scales applied for active citizenship in the European Union and the USA are shown together with the researchers. According to the table, it is seen that the size of citizenship values is in the 5 studies and it is seen that it is the most common dimension. Citizenship duties and protest dimensions are mentioned in two studies and it is seen that there is at least common dimension.

It is shown in Table 4. The dimensions of the scale applied in collaboration with researchers about active citizenship in Turkey. According to the table, the size of volunteering did not appear as a dimension in any study. It is seen that the size of most studies is citizenship value.

Turkey is transmitted by the scale of the work done in the US and European countries Tables 3 and 4 covered the years 2004 to 2017 are analyzed in the study conducted in Europe and Western countries, therefore it is seen that in a broader time frame.

Table 3. Matrix of active citizenship scales and dimensions in Europe and the United States

\begin{tabular}{|l|l|l|l|l|l|l|l|}
\hline Researcher & Knowledge & Skill & $\begin{array}{l}\text { Citizenship } \\
\text { Duties }\end{array}$ & Volunteering & Participation & Protest & $\begin{array}{l}\text { Citizenship } \\
\text { Values }\end{array}$ \\
\hline $\begin{array}{l}\text { Westheimer and Kahne } \\
(2004)\end{array}$ & $\mathrm{X}$ & & & & & $\mathrm{X}$ & $\mathrm{X}$ \\
\hline Hoskins (2006) & & $\mathrm{X}$ & & & & & $\mathrm{X}$ \\
\hline Kennedy (2007) & & $\mathrm{X}$ & $\mathrm{X}$ & & & \\
\hline Zaff et al. (2010) & & $\mathrm{X}$ & $\mathrm{X}$ & & $\mathrm{X}$ & & \\
\hline Hoskins er al. (2015) & $\mathrm{X}$ & $\mathrm{X}$ & & & $\mathrm{X}$ & $\mathrm{X}$ & $\mathrm{X}$ \\
\hline Lara et al. (2016) & $\mathrm{X}$ & & & $\mathrm{X}$ & $\mathrm{X}$ & & $\mathrm{X}$ \\
\hline $\begin{array}{l}\text { Rynkiewicz and Zalewska } \\
(2017)\end{array}$ & & & & & $\mathrm{X}$ & & $\mathrm{X}$ \\
\hline
\end{tabular}


Table 4. Scale and dimensions of active citizenship conducted in Turkey matrix table

\begin{tabular}{|c|c|c|c|c|c|c|c|}
\hline Researcher & Knowledge & Skill & $\begin{array}{c}\text { Citizenship } \\
\text { Duties }\end{array}$ & Volunteering & Participation & Protest & $\begin{array}{c}\text { Citizenship } \\
\text { Values }\end{array}$ \\
\hline Göz (2010) & $\mathrm{X}$ & & & & $\mathrm{X}$ & $\mathrm{X}$ \\
\hline Sağlam (2011) & $\mathrm{X}$ & $\mathrm{X}$ & $\mathrm{X}$ & & & $\mathrm{X}$ \\
\hline $\begin{array}{c}\text { Çevik-Kansu } \\
\text { and Oksuz } \\
\text { (2014) }\end{array}$ & & & & & $\mathrm{X}$ & $\mathrm{X}$ \\
\hline $\begin{array}{c}\text { Keçe and Dinç } \\
\text { (2015) }\end{array}$ & & $\mathrm{X}$ & & & & $\mathrm{X}$ & \\
\hline $\begin{array}{c}\text { Namli-Altıntas } \\
\text { and Kozaner } \\
\text { (2016) }\end{array}$ & & $\mathrm{X}$ & & & & & $\mathrm{X}$ \\
\hline $\begin{array}{c}\text { Yazici, Arslan, } \\
\text { Cetin and Dil } \\
(2017)\end{array}$ & & & & & $\mathrm{X}$ & $\mathrm{X}$ \\
\hline
\end{tabular}

\section{Discussion}

In this section, a literature review is done based on the dimensions of citizenship education.

Effective citizenship education also requires democratic education. Democratic education means liberating the mind and raising active and participatory individuals. It is a training program in which the mind is valued and the student can choose course materials for the topic integrity, and is a training process in which the teacher does not dictate and the student makes mental effort in classroom [14]. The democratic learning environment in which teachers and students voluntarily share their experiences within the classroom creates a learning environment that frees the student from being a passive recipient or teacher from dictating. In such a situation, it is possible to talk about individualization. A student who is active and participating in the school environment will be able to become an effective citizen. Barber [3] argues that citizenship education in democracy can be dealt with in at least three appropriate ways: formal pedagogy, individual social action and participatory politics. These forms enable citizens to become informed about politics as active participants. According to the National Curriculum Working Report, schools should create opportunities for students to develop their knowledge, understanding, skills and attitudes; they should become centers that students can make decisions at local and national level [24].

Effective citizenship education has been examined in three main categories, in a report published by the Advisory Group: social and ethical responsibility, community involvement and political literacy [25].

Effective citizenship education is related to the lifestyle and values of the whole school [33]. It is possible for effective citizenship education that the achievements of effective citizenship are included in the whole school program [29] implicit learning can be applied to effective citizenship education. Variations in school structure also affect effective citizenship education. If the factors that support effective citizenship education are defined as: background of school facilities, citizenship education (taught explicitly, taught as a class), school culture, classroom climate, school leadership, environment for student participation, informal learning experiences of students, informal inventory of learning outputs, then they can vary at a national level [38].

Effective citizenship education is created by the willingness of individuals to participate in civilian movements. This desire develops a sense of belonging for the individual and enables him to fulfill his potential [10].

Effective citizenship education is embodied in active learning in terms of participation dimension. The scope of this education (activities such as critical thinking, political literacy, identifying the needs of the community, learning how decisions are taken) can contribute to student's development at every level of education, from primary school to university [34]. A civic participation awareness that forms the democratic life expands one's individual learning and offers an opportunity for lifelong learning. Encouraging volunteer activities are recommended for this learning. The Active Learning for Active Citizenship (ALAC) program, developed in 2004, includes a participatory and community-based approach [2]. Therefore, the determining factor in state-citizen relations is that both sides voluntarily work for education and thus create the dimensions of effective citizenship education.

Student's contribution to social responsibility projects, discussion within the classroom are the activities that may help students become more active [13]. Students' playing an active role in the classroom, provide learning and influence learning motivation [25].

When assessment methods are considered, schools can reduce students' citizenship knowledge. Measuring student knowledge with test items can cause this effect [36]. To prevent this, a process based education should be applied. In general, there are 3 learning models related to effective citizenship. They are cognitive learning, pragmatic learning and effective learning. Cognitive learning is one's abilities, historical knowledge, his knowledge on political institutions, events and actors. Pragmatic learning is about 
taking actions based on the things learned. Effective learning is the application of specific attitudes, behaviors and values [10].

In this study, literary review also includes the dimensions. Increased state service for citizens, increased political participation, participation of citizens at local and national level are parallel with citizens' knowledge on effective citizenship [6]. Individuals having knowledge that require expertise and to express thoughts about the subject, to define the thought, to confirm, to support an opinion and to evaluate other opinions can be classified as participation skills [7]. Individuals having skills to read basic sources, expand reading areas, and writing their own ideas may be categorized as skills aimed to be gained from effective citizenship education [30]. ALAC defined these skills as civic listening, civic speaking, emotional literacy, intercultural understanding [2]

Presenting these skills with active participation shows that students can become an effective citizen [34]. On the other hand, participation in national elections and voluntarily establishing links with non-governmental organizations [35] are the basic factors of participation dimension. The knowledge and equipment to ensure the participation of students in effective citizenship education can be given during the learning process.

Awareness of equal moral values, participating in political and civic participation, becoming self-directed and supporting and maintaining the democratic principles and practices, are included in effective citizenship values [19].

Perspectives on effective citizenship education differ in Turkish and Western culture. The reason is that the political process is adopted by the state. The view on education is the main determinant of politics in Turkey and in the world. In developing countries such as Turkey, the dominant cultural elements play a role in education policy. Steenkamp and Loubser [40] have shown that nationalist values are dominant in Turkey. This situation affects participation dimension negatively. The fact that participation in NGOs is low [10] supports the efforts of creating apolitical citizens after 1980. On the other hand, the dominance of conservative and nationalistic views in Turkey [40] is due to the fact that there is state-centered mindset. The fact that protest dimension is seen as only a sub-category in the researches examined in this study proves this statement.

Cultural differences play an active role on citizenship values. Society's creation of a democracy culture can be regarded as directly proportional to the increase in effective citizenship indicators. Citizenship education has been brought to the global level with the concept of human rights-pluralism-multiculturalism-social relations in modern democratic regimes [39]. It is therefore inevitable that citizenship education becomes a state policy. In the model that validates family-school administration-student cooperation, individuals are expected to have political opinions [43].

\section{Conclusions}

The results of this study can be summarized as follows:

- When the scales used are evaluated based on a sample, it is seen that the scales made in European countries and USA are made by research companies. For this reason, the sample size is larger compared with the sample size of the scales in Turkey.

- When the common dimensions of effective citizenship education in this study are examined, the dimensions of knowledge, skills, participation, protest and citizenship have been found both in Turkish and Western culture.

- Effective citizenship education involves a wide spectrum of dimensions, ranging from knowledge to volunteerism and participation, in researches in Europe and America. In Turkey, these dimensions are slightly more limited.

- These researches construct the type of citizen that is desired for the future. For example, including the European Union countries in the study defines the profile of a European citizen.

- Finding common dimensions in scales applied in Turkey is difficult. However, in scales applied in USA and Europe, the common dimensions can be seen more easily. This is explained by the citizenship definition in Turkey and the policies in Europe and USA that aims to create a new type of citizen.

- The difference between the dimensions of effective citizenship education can be explained with culture. As the point of view regarding the state, society, politics and education changes, the dimensions of effective citizenship also change. This indicates state-citizen cooperation.

- Task-based understanding of citizenship in Turkey, was established based on the law in the European Union and the United States.

- The scale implementation studies related to citizenship began earlier than in the US and European countries to Turkey.

\section{REFERENCES}

[1] Andrews R., Cowell R. , Downe j. Martin S.\& D Turner, D. Supporting Effective Citizenship in Local Government: Engaging, Educating and Empowering Local Citizens, Local Government Studies, 2008. 34:4, 489-507, DOI: $10.1080 / 03003930802217462$

[2] Annette, J. Active Learning for Active Citizenship Democratic Citizenship and Lifelong Learning, Education, Citizenship and Social Justice, Vol.4, No.2, 149-160, 2009. 
[3] Barber, B. Güçlü Demokrasi.Strong Democracy Participatory Poititics for a New Age, İstanbul, Ayrınt, 1995.

[4] Bogdan, R., and S. K. Biklen. Qualitative research for education, London, Allyn and Bacon, 1982.

[5] Breg, B. L. Qualitative Research Methods for the Social Science, California State University, Long Beach, 2009.

[6] Branson, M. S. Education for citizenship and the teaching of democracy in schools, Paper presented at the Uluslararas1 Demokrasi Eğitimi Conference, On Sekiz Mart Üniversitesi Eğitim Fakültesi, May 19-24, 2004.

[7] CCE (Center for Civic Education). National standards for civics and government, California: Center for Civic Education, 1997.

[8] Correia, A. M. R. Information literacy for an active and effective citizenship. In White Paper prepared for UNESCO, the US National Commission on Libraries and Information Science, and the National Forum on Information Literacy, for use at the Information Literacy Meeting of Experts, Prague, The Czech Republic. Vol. 20, 1-30, 2002.

[9] Clark, M., and B. Missingham. Active Citizenship and Social Accountability, Development in Practice Vol.19, No.8, 955-963, 2009.

[10] Çakmaklı, D. Active Citizenship in Turkey: Learning Citizenship in Civil Society Organizations. Citizenship Studies Vo.19, No.3-4, 421-435, 2015.

[11] Çevik-Kansu, C., and Y. Öksüz. "Developing an Active Citizenship Scale for the Fourth Grade Primary School Students.”The Anthropologist Vo.18, No.3, 969-980, 2014.

[12] Danju, İ., and H.Uzunboylu. A Content Analysis of Citizenship Education." Global Journal on Humanities \& Social Sciences Vol.4, 167-173, 2016.

[13] Davies, I., and M. Evans. "Encouraging Active Citizenship." Educational Review Vol.54, No:1, 69-78, 2002.

[14] Dewey, J. Günümüzde Eğitim [EducationToday], Ankara: Pegem Akademi, 2011.

[15] Engel, R. J., and R. K. Schutt. The practice of research in social work, London: Sage, 2005.

[16] Eryılmaz, Ö., Bursa, S., Ersoy, A. F. Social Studies Teachers' and Students' Perceptions of Active Citizenship and Non-Governmental Organisations, International Online Journal of Educational Sciences, 10(2), 258-276, 2018.

[17] Europe Commission. Education and active citizenship in the European Union Office for official publications of the European Communites, Luxembourg, 1998.

[18] Göz, N. L. İlköğretimde demokrasi ve vatandaşlık eğitimi. Master Thesis, Uşak Üniversitesi Sosyal Bilimler Enstitüsü, Uşak, 2010.

[19] Hoge, J. D. "Character education, citizenship education, and the social studies." The Social Studies Vol.93, No.3, 103-108, 2002.

[20] Hoskins, B. Draft Framework on indicators for active citizenship, (Ispra, CRELL), 2006.

[21] Hoskins, B., D'hombres, B., \& Campbell, J. Does formal education have an impact on active citizenship behaviour? European educational research journal, 7(3), 386-402., 2008.

[22] Hoskins. B.,and M. Maschereini. Measuring Active Citizenship Through the Development of a Composite Indicator, Soc. Indic Res. Vol.90, 459-488, 2009.

[23] Hoskins, B., M. Saisana,and C. M. Villalba. "Civic Competence of Youth in Europe: Measuring Cross National Variation Through the Creation of a Composite Indicator."Soc. IndicRes, Vol.123, No.2, 431-457, 2015.

[24] Johnson, J. B., H. T., Reynolds, and J. D. Mycoff. Political Science Research Methods. Washington Dc, Cq Press, 2015.

[25] Jones, P. Action Learning for Citizenship Education. Pastoral Care in Education Vol.18, No.4, 19-25, 2000.

[26] Keçe, M.,and E. Dinç. "Demokratik Katılım Ölçeğinin Geliştirilmesi: Geçerlik ve Güvenirlik Çalışması.” Journal of Gazi Education Faculty, Vol.35, No.1, 177-207, 2015.

[27] Kennedy, J.K. "Student Contructions of 'Active Citizenship': What Does Participation Mean to Students?'British Journal of Educational Studies, Vol.55, No.3, 304-324, 2007.

[28] Lara, M. C., M. Deane, and M. Pavlakou. "Measuring Learning Gainin Active Citizenship in Higher Education." Brief Contents, 83-86, 2016.

[29] Lawson, H. 2001. "Active Citizenship in Schools and the Community." Curriculum Journal Vo.12 No.2, 163-178, 2001.

[30] Li, Z., and Y. Chungong. Reading-to Write: A Practice of Critical Thinking, Journal of Arts and Humanities. Vol.3, No.5, 67-71, 2014.

[31] Miles, M. B., and A. M. Huberman. Qualitative data analysis: An expanded sourcebook, London: Sage, 1994.

[32] Namlı-Altıntaş, İ. and Ç.,Kozaner. Sınıf Öğretmenliği ve Sosyal Bilgiler Öğretmenliği Adaylarının Aktif Vatandaşlık Değerleri Açısından Karşılaştırılması. The Journal of Academic Social Science, Vol.4, No.34, 505-518, 2016.

[33] Sağlam, H. İ. “Öğretmen Adaylarının Etkili Vatandaşlık Yeterlik Düzeyleri.” Kastamonu Üniversitesi Kastamonu Eğitim Dergisi, Vol.19, No.1, 39-50, 2011.

[34] Potter, J. Active citizenship in schools. London, Kogan Page, 2012.

[35] Prior, D., Stewart J., and K. Walsh. Citizenship Rights, Community and Participation. London, Pitman, 1995.

[36] Rothstein, R., and R. Jacobsen. Measuring Social Responsibility." Educational Leadership, Vol.66, No.8, 14-19, 2009.

[37] Rynkiewicz, B. K., and A. M. Zaleska, "Measuring Young People's Citizenship Activity, Citizenship Teaching \& Learning, Vol.12, No.2, 141-150, 2017.

[38] Scheerens, J. "Indicators on Informal Learning for Active Citizenship At School, Educ Asse Eval, Vol.23, No.3, 201$222,2011$.

[39] Schulz, W., J. Ainley, and J. Fraillon, ICCS 2009 Technical Report, 2011 
[40] Steenkamp, C., and R. Loubser. Active Citizenship: A Comparative Study of Selected Young and Established Democracies.Politicon, Vol.43 No.1, 117-134, 2016.

[41] Yazıcı, S. H. Arslan, E. Çetin, E. and K. Dil. Aktif Yurttaşlık Ölçme Aracının Geliştirilmesi Üzerine Bir Çalışma, Turkish Studies, Vol.12, No.2, 251-272, 2017.

[42] Westheimer, J.,and J. Kahne, "What kind of citizen? The politics of educating for democracy." American Educational Research Journal, Vol.41, No.2, 237-269, 2004.

[43] Wood, J. "Preferred Futures: Active Citizenship, Government and Young People, Voices Youth\&policy105: 50-70, 2010.

[44] Zaff, J., M. Boyd, Y., Li, J.V. Lerner, and R. M. Lerner. "Active and Engaged Citizenship: Multi-Group and Longitudinal Factorial Analysis of an Integrated Construct of Civic Engagement." Journal of Youth and Adolescence, Vol.39, No.7, 736-750, 2010.

[45] Zalewska, A. M., and B. Krzywosz-Rynkiewicz. "Psychologiczne portrety młodych obywateli." Rozwojowe i podmiotowe uwarunkowania aktywności obywatelskiej młodzieży, Warszawa: Academica, 2011 